\title{
DEVELOPMENT OF AN ECO-EFFICIENT PRODUCT/PROCESS FOR THE VULCANISING INDUSTRY
}

\author{
M.B. Becerra ${ }^{1} *$, R. Zitzumbo ${ }^{2}$, J. Domínguez ${ }^{3}$, J.L. García ${ }^{4}$, S. Alonso ${ }^{5} \&$ A. Hernández ${ }^{6}$ \\ ${ }^{1,2,5}$ Department of Material Sciences \\ CIATEC, A. C, León, Guanajuato, México \\ ${ }^{1}$ mbecerra.picyt@ciatec.mx, ${ }^{2}$ rzitzumb@ciatec.mx, ${ }^{5}$ salonso@ciatec.mx \\ ${ }^{3}$ Department of Mathematics and Statistics \\ CIMAT, Aguascalientes, México \\ jorge@cimat.mx \\ ${ }^{4}$ Department of Industrial and Manufacturing Engineering \\ UACJ, Ciudad J uárez, México \\ jorge.garcia@uacj.mx \\ ${ }^{6}$ Department of Robotic Engineering \\ UPG, Cortazar, Guanajuato, México \\ ahernandez@upgto.edu.mx
}

\begin{abstract}
This paper presents the development of an eco-efficient product/process, which has improved mechanical properties from the introduction of natural fibres in the EPDM (Ethylene-Propylene-Diene-Terpolymer) rubber formulation. The optimisation analysis is made by a fractional factorial design $2^{11-7}$. Different formulations were evaluated using a multi-response desirability function, with the aim of finding efficient levels for the manufacturing time-cycle, improving the mechanical properties of the product, and reducing the raw material costs. The development of an eco-efficient product/process generates a sustainable alternative to conventional manufacturing.
\end{abstract}

\section{OPSOMMING}

Die ontwikkeling van ' $n$ omgewingsdoeltreffende produk of proses, wat verbeterde meganiese eienskappe het as gevolg van die toevoeging van natuurlike vesels in die EPDM (' $n$ tipe polimeer) rubber formulering word voorgehou. Die optimiseringsanalise is gedoen deur ' $n$ breukdeel faktoriaal ontwerp $2^{11-7}$. Verskillende formulerings is geëvalueer deur ' $n$ multi-reaksie wenslikheidsfunksie met die doel om doeltreffende vlakke vir die vervaardigingstydsiklus te vind en sodoende die meganiese eienskappe van die produk te verbeter en die roumateriaalkoste te verminder. Die ontwikkeling van ' $n$ omgewingsdoeltreffende produk of proses genereer ' $n$ volhoubare alternatief tot konvensionele vervaardiging.

\footnotetext{
${ }^{1}$ The author was enrolled for a PhD (Industrial Engineering) degree in the Department of Material Sciences, CIATEC-CONACYT

${ }^{3}$ The author was enrolled for a PhD (Mathematics and Statistics) degree in the Department of Mathematics and Statistics, CIMAT.

${ }^{4}$ The author was enrolled for a PhD (Industrial Engineering) degree in the Department of Industrial and Manufacturing Engineering, UAC) .

${ }^{6}$ The author was enrolled for a Masters (Mechanical Engineering) degree in the Department of Robotic Engineering, UPG.

* Corresponding author
} 


\section{INTRODUCTION}

Some decades ago, thermoplastic materials replaced metal in the automotive sector when they were accepted as engineering materials. Due to demand, thermoplastics have increased up to $20 \%$ in cost. This increased cost created the need for employing fillers in thermoplastic materials to generate compounds and reduce costs. Among the reinforcements recently used are natural fibres, which offer a lot of advantages; they are low in cost, have a low density, and they are renewable, abundant, and environmentally friendly. Natural fibres also have a high degree of flexibility during processing, and do not damage the equipment [1].

\subsection{Natural fibres in the industry and conventional processes}

While many researchers have focused on the use of natural fibres as an alternative material, government entities have been seeking to establish new policies for the use and handling of materials to ensure that there is as little negative impact as possible on the environment. The industrial sector, on the other hand, is searching for greater acceptance of green products and environmentally-friendly processes, which include the introduction of natural fibres. Table 1 presents examples of work involving natural fibres that has been conducted by researchers within different process groups.

Table 1: Studies with natural fibres

\begin{tabular}{|c|c|c|c|c|}
\hline Process & Author & Fibre type & Obtained product & Application \\
\hline \multirow{9}{*}{$\begin{array}{l}\text { Injection } \\
\text { moulding }\end{array}$} & Amigó et al. (2008) & $\begin{array}{l}\text { Cotton } \\
\text { Flax } \\
\text { Sisal } \\
\text { Hemp } \\
\text { Fique } \\
\text { Kenaf [2] }\end{array}$ & $\begin{array}{l}\text { HDPE compound } \\
\text { recycled/ cotton. } \\
\text { HDPE compound } \\
\text { recycled/flax. } \\
\text { HDPE compound } \\
\text { recycled/ sisal. } \\
\text { HDPE compound } \\
\text { recycled/ hemp. } \\
\text { HDPE compound } \\
\text { recycled/ fique. } \\
\text { HDPE compound } \\
\text { recycled/ kenaf. }\end{array}$ & Textile sector \\
\hline & $\begin{array}{l}\text { Ruksakulpiwat et al. } \\
(2009)\end{array}$ & Vetiver grass [3] & $\begin{array}{l}\text { NR/ vetiver/ PP } \\
\text { compound. } \\
\text { PP/ EPDM/ vetiver } \\
\text { compound. }\end{array}$ & Industrial \\
\hline & $\begin{array}{l}\text { Shoj aei and } \\
\text { Fereydoon (2009) }\end{array}$ & $\begin{array}{l}\text { Short glass fibre } \\
{[4]}\end{array}$ & $\begin{array}{l}\text { PA6/ glass fibre/ EPR-g- } \\
\text { MA compound. }\end{array}$ & Industrial \\
\hline & Gava et al. (2010) & $\begin{array}{l}\text { Short silica fibre } \\
\text { [5] }\end{array}$ & $\begin{array}{l}\text { Nylon 6/ EPDM-g-MA } \\
\text { compound. }\end{array}$ & Variety \\
\hline & Seong et al. (2011) & Carbon [6] & $\begin{array}{l}\text { Carbon fibre/ PA6 } \\
\text { compound. }\end{array}$ & $\begin{array}{l}\text { Automotive } \\
\text { industry }\end{array}$ \\
\hline & Kord (2011) & Wood flour [7] & $\begin{array}{l}\text { PP/ wood flour/ PP-MA } \\
\text { compound. }\end{array}$ & $\begin{array}{ll}\text { For } & \text { watery } \\
\text { media } & \end{array}$ \\
\hline & Zhao et al. (2011) & Rice straw [8] & $\begin{array}{l}\text { PLA/ rice straw } \\
\text { compound. }\end{array}$ & $\begin{array}{ll}\text { Packing } & \text { film } \\
\text { for food }\end{array}$ \\
\hline & Becerra et al. (2011) & $\begin{array}{l}\text { Agave fibre } \\
\text { (Tequilana } \\
\text { Weber) [9] }\end{array}$ & $\begin{array}{l}\text { LDPE/ tequilana agave } \\
\text { compound. }\end{array}$ & Industrial \\
\hline & $\begin{array}{l}\text { Chaochanchaikul et } \\
\text { al. (2012) }\end{array}$ & $\begin{array}{l}\text { Sawdust particles } \\
\text { [10] }\end{array}$ & $\begin{array}{l}\text { Saw dust } \\
\text { particles/ HDPE } \\
\text { compound. }\end{array}$ & Construction \\
\hline
\end{tabular}


Table 1: Studies with natural fibres (continued)

\begin{tabular}{|c|c|c|c|c|}
\hline Process & Author & Fibre type & Obtained product & Application \\
\hline \multirow{10}{*}{$\begin{array}{l}\text { Compression } \\
\text { moulding }\end{array}$} & $\begin{array}{l}\text { Herrera and } \\
\text { Valadéz (2005) }\end{array}$ & Henequen [11] & PE/ henequen compound. & Industrial \\
\hline & $\begin{array}{l}\text { Sanjuan and } \\
\text { J asso (2009) }\end{array}$ & $\begin{array}{l}\text { Agave fibre } \\
\text { (Tequilana } \\
\text { Weber) } \\
\\
\text { Henequen [12] }\end{array}$ & $\begin{array}{l}\text { PP virgin/tequilana agave/ PP- } \\
\text { MA compound. } \\
\text { PP recycled/ tequilana } \\
\text { agave/ PP-MA compound. } \\
\text { PP re-processed/ henequen/ PP- } \\
\text { MA. } \\
\text { PP post- } \\
\text { consumer/ henequen/ PP-MA } \\
\text { compound. }\end{array}$ & Industrial \\
\hline & $\begin{array}{l}\text { Ismail and } \\
\text { Shaari (2010) }\end{array}$ & $\begin{array}{l}\text { Ash palm and } \\
\text { halloysite [13] }\end{array}$ & $\begin{array}{l}\text { Palm ash/ halloysite } \\
\text { nanotubes/ EPDM compound. }\end{array}$ & Marketing \\
\hline & $\begin{array}{l}\text { Anuar and } \\
\text { Zuraida (2011_ }\end{array}$ & Kenaf [14] & $\begin{array}{l}\text { Thermoplastic NR/ kenaf } \\
\text { compound. } \\
\text { PP/ EPDM compound. }\end{array}$ & $\begin{array}{l}\text { Automotive } \\
\text { components }\end{array}$ \\
\hline & $\begin{array}{l}\text { Valente et al. } \\
\text { (2011) }\end{array}$ & $\begin{array}{l}\text { Recycled glass } \\
\text { fibre [15] }\end{array}$ & $\begin{array}{l}\text { LDPE/ wood compound. } \\
\text { LDPE/ wood/ glass fibre } \\
\text { compound. } \\
\text { LDPE/ wood/ glass } \\
\text { fibre/ recycled glass fibre } \\
\text { compound. } \\
\text { PP/ wood compound. } \\
\text { PP/ wood/ glass fibre } \\
\text { compound. } \\
\text { PP/ wood/ glass fibre/ recycled } \\
\text { glass fibre compound. }\end{array}$ & Industrial \\
\hline & $\begin{array}{l}\text { Viet et al. } \\
(2011)\end{array}$ & $\begin{array}{l}\text { Kenaf powder } \\
\text { [16] }\end{array}$ & $\begin{array}{l}\text { Kenaf powder/HDPE } \\
\text { recycled/ NR/ PE-MA compound. }\end{array}$ & Marketing \\
\hline & $\begin{array}{l}\text { Zabihzadeh et } \\
\text { al. (2011) }\end{array}$ & $\begin{array}{l}\text { Rapeseed stems } \\
\text { [17] }\end{array}$ & PP/ rapeseed compound. & Panels \\
\hline & $\begin{array}{l}\text { Najafi and } \\
\text { Khademi } \\
\text { (2011) }\end{array}$ & $\begin{array}{l}\text { Rice husks flour } \\
\text { Sawdust and } \\
\text { panels flour } \\
{[18]}\end{array}$ & $\begin{array}{l}\text { HDPE recycled/ rice husks flour } \\
\text { compound. } \\
\text { HDPE recycled/ sawdust flour } \\
\text { compound. } \\
\text { HDPE recycled/ sanded panel } \\
\text { flour compound. }\end{array}$ & Panels \\
\hline & $\begin{array}{l}\text { Singha and } \\
\text { Rana (2012) }\end{array}$ & $\begin{array}{l}\text { Americana } \\
\text { agave [19] }\end{array}$ & $\begin{array}{l}\text { PS/ Americana agave/ MMA } \\
\text { compound. }\end{array}$ & Wire coating \\
\hline & $\begin{array}{l}\text { Safwan et al. } \\
\text { (2013) }\end{array}$ & $\begin{array}{l}\text { Palm kernel } \\
\text { Shell [20] }\end{array}$ & $\begin{array}{l}\text { Palm kernel shell/ PP/ palm } \\
\text { nanosilica. } \\
\text { Almond shells/ PP compound. }\end{array}$ & Automotive \\
\hline \multirow[t]{2}{*}{ Extrusion } & $\begin{array}{l}\text { Mahdavi et al. } \\
\text { (2010) }\end{array}$ & Date palm [21] & Date palm/ HDPE compound. & $\begin{array}{c}\text { Commercial } \\
\text { use }\end{array}$ \\
\hline & $\begin{array}{l}\text { Acharya et al. } \\
\text { (2011) }\end{array}$ & $\begin{array}{l}\text { Sugar cane } \\
\text { bagasse [22] }\end{array}$ & $\begin{array}{l}\text { Sugar cane bagasse/ epoxy } \\
\text { compound. }\end{array}$ & $\begin{array}{c}\text { Several } \\
\text { applications }\end{array}$ \\
\hline $\begin{array}{l}\text { Rotational } \\
\text { moulding }\end{array}$ & $\begin{array}{l}\text { López et al. } \\
\text { (2012) }\end{array}$ & $\begin{array}{l}\text { Agave fibre } \\
\text { (Tequilana } \\
\text { Weber) [23] }\end{array}$ & $\begin{array}{l}\text { LMDPE/ tequilana agave } \\
\text { compound. }\end{array}$ & Industrial \\
\hline Mixing & $\begin{array}{l}\text { Lárusson et al. } \\
\text { (2013) }\end{array}$ & $\begin{array}{l}\text { Polyvinyl } \\
\text { alcohol fibres } \\
{[24]}\end{array}$ & $\begin{array}{l}\text { Reinforced with cement and } \\
\text { fibre compound. }\end{array}$ & $\begin{array}{l}\text { Concrete } \\
\text { panels }\end{array}$ \\
\hline Fibre wash & $\begin{array}{l}\text { Alawar et al. } \\
\text { (2009) }\end{array}$ & $\begin{array}{l}\text { Date palm tree } \\
\text { fibres [1] }\end{array}$ & Date palm tree fibre. & Textile \\
\hline
\end{tabular}

\subsection{Research problem and objectives}

The aim of this research was to investigate and develop a new alternative for the disposal of tequila agro-industries' waste in Mexico [23]. The great amount of waste generated after extracting tequila juice is causing environmental problems $[25,27]$. This waste can be used as a rubber reinforcement to improve the mechanical properties of the product, reduce time in the manufacturing cycle, and decrease costs of raw materials. 
The objective of this work is to develop a sustainable vulcanised EPDM (Ethylene-propylenediene-terpolymer) rubber product by introducing natural agave fibres in the formulations, using a non-conventional manufacturing process with a multi-response desirability function where mechanical properties are improved, costs of raw materials are decreased, and the manufacturing time is evaluated.

\section{METHODOLOGY}

\subsection{The strategy for designing experiments using the response is summarised as follows:}

1. Determination of factors, levels and response variables.

A brainstorming exercise was carried out among a group of experts to identify all the factors affecting the process and product. A cause-effect diagram was then used to determine the factors and levels according to the technological knowledge of the process, combining practical experience and written reports. The response variables were determined according to the client's quality specifications and the manufacturer's interest in the process's operational conditions [28, 30].

2. Determination of the fractional factorial design considering costs and time $[28,30]$.

3. Statistical data analysis was carried out through a technical variance analysis (ANOVA), normally used in experiment design [28, 30].

4. Obtaining a regression equation to interpret the process behaviour according to Castaño and Domínguez (2010) [28] and Gutiérrez and De La Vara (2008) [30].

$$
Y_{j}=\beta_{0}+\sum_{i=1}^{\mathrm{k}} \beta_{0} \mathrm{X}_{\mathrm{i}}+\varepsilon
$$

5. Process optimisation through the multi-response desirability function $[28,30]$.

A general focus of the multi-response function is that after the regression equations are found and properly adjusted, it can proceed through the individual desirability function $d_{j}$ to give desirable values to each of the response variables. The $d_{j}$ value is found in the interval $0 \leq d_{j} \leq 1$. If $d_{j}$ is 1 , then the value of the variable is the most desirable, however if $d_{j}$ is 0 , the variable is not desirable [28]. The value for $d_{j}$ is given by equation (2).

$$
d_{j}=\left\{\begin{array}{c}
\left(\frac{\hat{y}_{j}-L I E_{j}}{T_{j}-L I E_{j}}\right)^{s}, \text { si } \quad L I E_{j} \leq \hat{y}_{j} \leq T_{j} \\
\left(\frac{\hat{y}_{j}-L S E_{j}}{L S E_{j}-T_{j}}\right)^{t}, \text { si } T_{j} \leq \hat{y}_{j} \leq L S E_{j} \\
0 \text { si } \hat{y}_{j} \geq L S E_{j} \text { o } \hat{y}_{j} \leq L I E_{j}
\end{array}\right.
$$

where $\hat{y}_{j}$ is the predicted value for the response variable; LIE $_{j}$ is the inferior specification limit; $\mathrm{LSE}_{\mathrm{j}}$ is the superior specification limit; $\mathrm{T}_{\mathrm{j}}$ is the most desirable value; $\mathbf{s}$ and $\mathbf{t}$ are exponents to select the required form of desirability in each response. Global desirability (D) is considering all the response variables through their desirability functions; a method proposed by Derringer and Suich [31], which is to maximise D, known as the geometrical measure of $d_{1}, d_{2, \ldots} d_{m}[28,30]$.

$$
\boldsymbol{D}=\left(d_{1}^{w 1} x d_{2}^{w 2} x \ldots x d_{m}^{w m}\right)^{1 / \Sigma w_{1}}
$$

where $W_{i}$ weights are steady, allowing the relative importance of each response variable to be balanced. The higher the weight given to a variable in relation to the remaining variables, the greater the weight in the optimisation. 
In other words, if all variables are equally important, $W_{i}$ is equal to 1 . Note that the exponent $s$ and $t$ can be introduced as part of the $W_{i}$ weights $[28,30]$.

For the procedure applying the desirability function, regression equations were constructed separately from each response, and were then determined by weighting the responses respectively to minimise, maximise, and maintain.

Afterwards, the multi-response optimisation was carried out, considering the importance of each response, comparing it with the others, and seeking a solution in which all the responses had an acceptable level. The $D$ desirability function is measured on a scale of 0 to 1 . The closer the value of the $D$ global desirability function to 1 , the more acceptable the product $[28,30]$.

\section{EXPERIMENTAL}

The following equipment and materials were used in the experiment:

\subsection{Equipment}

Brabender internal mixer (DDRV-502). Brabender external mixer (PM-3000). Hydraulic press (Carver 38954DI1A00). Imperial stove V. Sartorius analytic scale (AG BP 4100). Rheometer oscillating disc (ODR 2000). Steel mould ( $150 \mathrm{~mm} \times 150 \mathrm{~mm} \times 3 \mathrm{~mm}$ ). Standard die cut tear strength (ASTM-D624). Standard die cut elongation at break (ASTM-D412). Die cutting pneumatic (ATOM SE-20-C-C). Durometer type Shore A PT\#T588-59 (ASTM-D2240). Instron machine 365.

\subsection{Materials}

EPDM IP 4725P (Dow Nordel $®$ ), viscosity Mooney ML1+4 a $125^{\circ} \mathrm{C}, 70 \%$ of ethylene. Molecular medium weight distribution. Thermal carbon black (N990®Degussa). Stearic acid (Vstearin ${ }^{\circledR}$ SA29). Zinc oxide (xzinal 821 active). Parafinic oil (324). Benzotiacyle disulfide (MBTS). Tiuram disulfide ultra accelerators (TMTD). Compatibilising agent EPDM-MA (Fusabond N MF-4160 Dupont $\left.{ }^{\circledR}\right)$. Sulphur in powder $[3,32,33]$ and agave fibre (Tequilana Weber) $[9,12,23]$.

\section{METHOD OF MANUFACTURING}

Agave fibre (Tequilana Weber) was dried in a stove for 24 hours at $80^{\circ} \mathrm{C}$ to remove any moisture $[11,34,35]$.

The production of tequila begins with the planting of agave (the Weber Tequilana plant, which is native to Mexico). The plant must mature between 7 and 10 years. Once mature, the leaves of the plant are removed, leaving the pineapple, which weighs about $150 \mathrm{~kg}$.

After extracting the juice from the agave for the tequila production process, the industry generates a large amount of solid waste. For example, $8 \mathrm{~kg}$ of bagasse are generated for every litre of tequila. One ton of bagasse has approximately $70 \mathrm{~kg}$ of fibre and $350 \mathrm{~kg}$ of pulp as reusable sub-products.

\subsection{Preparation of raw material}

An analytical scale was used to weigh all the components used in the different formulations for each experimental treatment. Carbon black $(40,80 \mathrm{PCH})$, paraffinic oil $(15,40 \mathrm{PCH})$, stearic acid $(0.5,2 \mathrm{PCH})$, zinc oxide (3, $5 \mathrm{PCH})$, EPDM-MA (2, $7 \mathrm{PCH})$, MBTS $(0.7,2 \mathrm{PCH})$, $\operatorname{TMTD}(0.1,0.6 \mathrm{PCH})$, agave fibre (Tequilana Weber in Mexico) $(10,40 \mathrm{PCH})$ and vulcanising agent $(1,2.5 \mathrm{PCH})[32,36,39]$. 


\subsection{Programming of operational parameters}

Operational parameters were set for the internal mixer $\left(120^{\circ} \mathrm{C}, 50 \mathrm{rpm}, 10\right.$ minutes) [16, 20], external mixer $\left(120^{\circ} \mathrm{C}, 20 \mathrm{rpm}\right)$ and hydraulic press $\left(160^{\circ} \mathrm{C}, 7\right.$ and 10.5 minutes) [ 11 , $13,19,38,41]$. The mould was allowed to preheat inside the press.

\subsection{Manufacturing of rubber/fibre product}

The process, which started in the internal mixer, mixed the components for 10 minutes. The EPDM rubber melted in one minute. Next, stearic acid, ZnO, EPDM-MA, MBTS and TMTD, was added and mixed for three minutes. Afterwards, black carbon and paraffinic oil were added and mixed for one minute. Immediately after this, fibre was added and mixed for two minutes, and lastly sulphur was added and mixed for three minutes. The mixture was removed, and $20 \mathrm{~g}$ was weighed and laminated in the external mixer. The rest of the mixture was poured into the preheated mould, producing $3 \mathrm{~mm}$ thick sheets $[38,39,42$, 44]. The description of the non-conventional process of fabricating vulcanised rubber for the rubber/fibre product is shown in Figure 1.

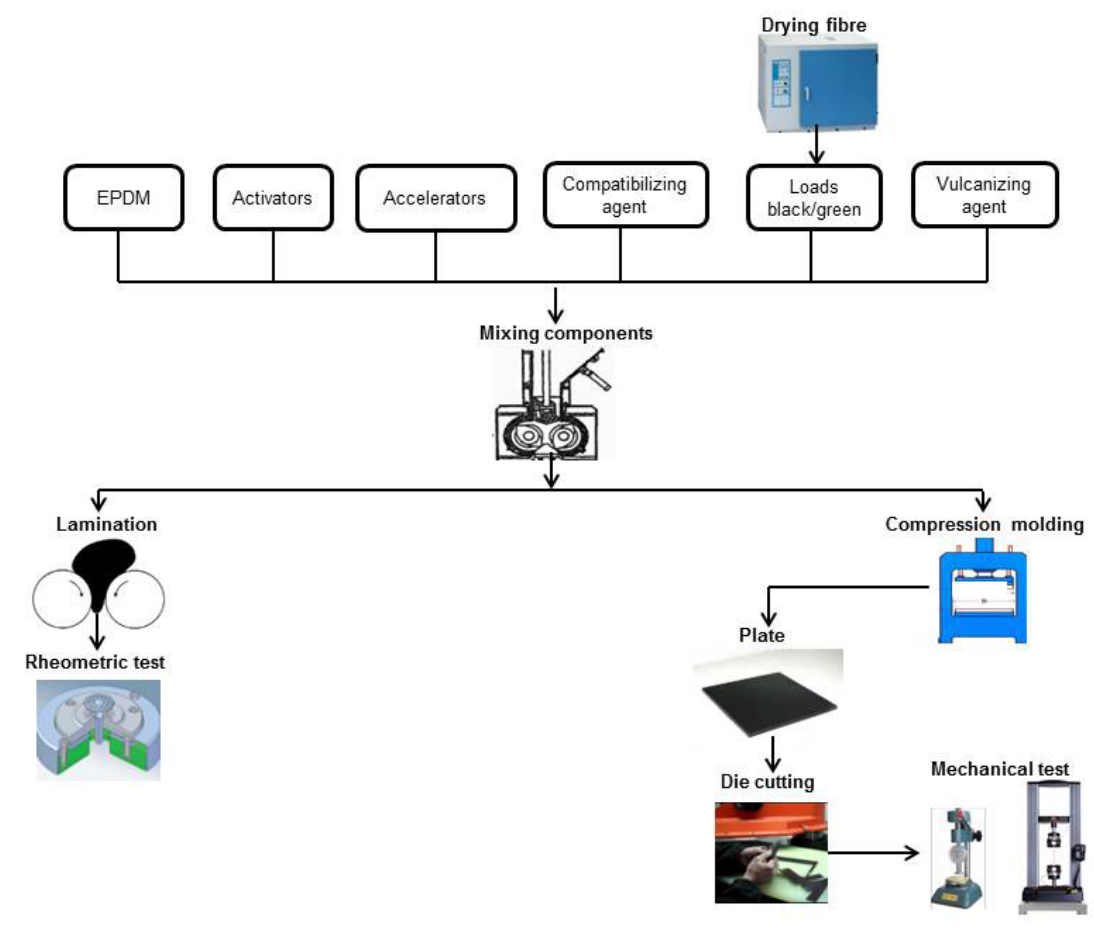

Figure 1: Diagram of the non-conventional process of fabricating vulcanised rubber with natural fibre

\subsection{Rubber/fibre product testing}

Rheometric tests were made (curves of vulcanisation) in an oscillating disc rheometer to obtain the manufacturing cycle time (MCT) $[33,43]$ and raw material cost (CM). Elongation at break (EB) tests were made in an Instron machine 365 (ASTM-D412) with a velocity of 500 $\mathrm{mm} / \mathrm{min}[41,43]$. The hardness (HSA) tests were made with durometer type Shore A (ASTMD2240) $[41,43]$. Tear strength (TR) tests were made (ASTM-D624) with a velocity of 400 $\mathrm{mm} / \mathrm{min}$ in an Instron machine 365.

\section{EXPERIMENTAL DESIGN}

The two types of experimental design used in this investigation are a fractional design $2_{\text {III }}^{11-7}$ = 16 experiment [28], and a non-replicated design of resolution III. In these resolution III designs, the principal effects are not alias among them can be consulted [28], but there are 
principal effects that are alias of double interaction [28, 30]. The variables were established using a codification high value 1 and low value -1 according to the Yates nomenclature $[29,30]$. The quantitative factors, levels and five-response variables are presented in Table 2. The objective is to determine whether the change in the levels of factors has a statistically significant effect on the response variables of the rubber/fibre product and non-conventional vulcanising process.

Table 2: Experimental factors and levels

\begin{tabular}{|c|c|c|c|c|}
\hline Factors & Code & $\begin{array}{c}\text { Le } \\
\text { Low } \\
-1\end{array}$ & $\begin{array}{c}\text { rels } \\
\text { High } \\
1 \\
\end{array}$ & $\begin{array}{l}\text { Measurement } \\
\text { Units }\end{array}$ \\
\hline Carbon black & A & 40 & 80 & $\mathrm{PCH}^{\mathrm{a}}$ \\
\hline Paraffinic oil & B & 15 & 40 & $\mathrm{PCH}$ \\
\hline Stearic acid & C & 0.5 & 2 & $\mathrm{PCH}$ \\
\hline Zinc oxide & $\mathrm{D}$ & 3 & 5 & $\mathrm{PCH}$ \\
\hline EPDM-MA & $E$ & 2 & 7 & $\mathrm{PCH}$ \\
\hline MBTS & $\mathrm{F}$ & 0.7 & 2 & $\mathrm{PCH}$ \\
\hline TMTD & G & 0.1 & 0.6 & $\mathrm{PCH}$ \\
\hline Fibre & $\mathrm{H}$ & 10 & 40 & $\mathrm{PCH}$ \\
\hline Sulphur & 1 & 1 & 2.5 & $\mathrm{PCH}$ \\
\hline Vulcanisation time & J & 7 & 10.5 & minutes \\
\hline Mixing temperature & $\mathrm{K}$ & 105 & 120 & ${ }^{\circ} \mathrm{C}$ \\
\hline
\end{tabular}

\section{RESULTS AND DISCUSSIONS}

The results of the experiments are shown in Table 3. The experimental treatments were made in a random order, and the experimental data was analysed using Statgraphics and Minitab.

\subsection{Variances analysis MCT, CM, EB, HAS, and TR}

With these results, an ANOVA analysis of each response variable was made separately to see what factors played an important role in the process and product (see Table 4). The procedure for the variance analysis can be consulted [28, 30]; some effects have P-values less than 0.05 , indicating that they are statistically significant.

\subsection{Multi-response optimisation}

The desirability function was proposed by Harrington [45], and improved by Derringer and Suich [31]. The multi-response optimisation determines the best factor and experimental levels arrangement in order to fulfil the requirements of the desired response variables at an optimal point $[28,30]$.

The desirability function method is applied to the regression equations (4), (5), (7) and (8), based on the product quality specifications and the manufacturer's interest where MCT and CM are minimised; EB and TR are maximised and HAS is maintained in 70 Shore A. The regression equation (6) was not included in the estimate of the desirability function, because it was not significant [28].

The results from the optimisation that applied the multi-response desirability function are shown in Figure 2, where two non-significant factors (stearic acid and mixing temperature) were removed. Note that there are factors that have non-significant effects in some responses; however, they were included because they can have significant results in the other responses. 
Table 3: Results experimental design $2_{\text {III }}^{11-7}$

\begin{tabular}{ccccccccccccccccc}
\hline \multicolumn{11}{c}{} \\
\hline Exp. & A & B & C & D & E & F & G & H & I & J & K & MCT $^{\text {a }}$ & CM $^{\mathrm{b}}$ & EB $^{\mathrm{C}}$ & HSA $^{\mathrm{d}}$ & TR $^{\mathrm{e}}$ \\
\hline 1 & 1 & -1 & -1 & 1 & 1 & 1 & -1 & -1 & 1 & -1 & -1 & 9.3 & 15.1 & 676.4 & 79.6 & 40.4 \\
2 & -1 & 1 & 1 & 1 & -1 & 1 & -1 & -1 & -1 & -1 & -1 & 10.6 & 14.0 & 892.5 & 67.6 & 31.3 \\
3 & -1 & 1 & 1 & -1 & -1 & -1 & 1 & 1 & 1 & -1 & -1 & 9.7 & 12.8 & 844.7 & 80.6 & 33.3 \\
4 & -1 & -1 & -1 & 1 & -1 & 1 & 1 & 1 & -1 & 1 & 1 & 9.2 & 14.6 & 611.3 & 71.3 & 40.0 \\
5 & 1 & -1 & 1 & 1 & -1 & -1 & 1 & -1 & -1 & -1 & 1 & 7.7 & 14.0 & 648.1 & 69.6 & 47.1 \\
6 & -1 & -1 & 1 & 1 & 1 & -1 & -1 & 1 & 1 & 1 & -1 & 7.3 & 15.6 & 407.1 & 74.3 & 33.2 \\
7 & 1 & -1 & 1 & -1 & -1 & 1 & -1 & 1 & 1 & -1 & 1 & 10.2 & 13.0 & 644.1 & 79.00 & 43.1 \\
8 & -1 & -1 & -1 & -1 & -1 & -1 & -1 & -1 & 1 & 1 & 1 & 9.7 & 15.9 & 833.7 & 71.3 & 41.5 \\
9 & -1 & 1 & -1 & -1 & 1 & 1 & -1 & 1 & -1 & -1 & 1 & 10.4 & 13.9 & 770.4 & 75.6 & 35.9 \\
10 & 1 & 1 & -1 & -1 & -1 & 1 & 1 & -1 & 1 & 1 & -1 & 8.1 & 15.0 & 673.5 & 62.0 & 34.7 \\
11 & 1 & -1 & -1 & -1 & 1 & -1 & 1 & 1 & -1 & -1 & -1 & 7.7 & 14.0 & 149.0 & 81.0 & 46.2 \\
12 & -1 & 1 & -1 & 1 & 1 & -1 & 1 & -1 & 1 & -1 & 1 & 8.5 & 15.1 & 649.1 & 71.0 & 28.8 \\
13 & 1 & 1 & -1 & 1 & -1 & -1 & -1 & 1 & -1 & 1 & -1 & 9.8 & 14.0 & 783.5 & 64.3 & 31.8 \\
14 & 1 & 1 & 1 & -1 & 1 & -1 & -1 & -1 & -1 & 1 & 1 & 10.3 & 15.8 & 953.1 & 70.0 & 35.2 \\
15 & 1 & 1 & 1 & 1 & 1 & 1 & 1 & 1 & 1 & 1 & 1 & 8.1 & 14.9 & 598.3 & 60.3 & 31.3 \\
16 & -1 & -1 & 1 & -1 & 1 & 1 & 1 & -1 & -1 & 1 & -1 & 9.6 & 17.2 & 689.8 & 66.3 & 40.5 \\
\hline
\end{tabular}

a Manufacturing cycle time measurement unit: minutes

${ }^{\mathrm{b}}$ Cost of raw materials measurement unit: Mexican pesos

c Elongation at break measurement unit: \%

${ }^{d}$ Hardness measurement unit: Shore A

e Tear strength measurement unit: KN/m

Table 4: Results from the ANOVA analysis

\begin{tabular}{|c|c|c|c|}
\hline ANOVA & $\begin{array}{l}\text { Significant } \\
\text { factors }\end{array}$ & Discussion & $\begin{array}{l}\text { Regression equations } \\
\text { derivate from(1) }\end{array}$ \\
\hline TR & $\begin{array}{l}A \\
B \\
D \\
I\end{array}$ & $\begin{array}{l}\text { A is a reinforcement that allows partial } \\
\text { immobilisation in rubber chains, increasing } \\
\text { tearing strength. } \\
B \text { is used to give flexibility to the product. } \\
D \text { is an activator that accelerates the reaction } \\
\text { with sulphur. } \\
I \text { is the cross-linking agent used to make the } \\
\text { vulcanising reaction. }\end{array}$ & $\begin{array}{l}\text { TR=37. } 18+1.59 \mathrm{~A}-4.36 \mathrm{~B}- \\
1.65 \mathrm{D}- \\
0.70 \mathrm{E}+0.006 \mathrm{~F}+0.59 \mathrm{G}- \\
0.29 \mathrm{H}-1.36 \mathrm{I}-1.12 \mathrm{~J}\end{array}$ \\
\hline MCT & G & $\begin{array}{l}\text { Organic composite that releases sulphur when it } \\
\text { reaches vulcanisation temperatures, forming } \\
\text { cross-linkages. G increases the vulcanising time } \\
\text { for the rubber/ fibre product, which decreases } \\
\text { the manufacturing cycle time in the new non- } \\
\text { conventional process of fabricating vulcanised } \\
\text { rubber for the rubber/fibre product. }\end{array}$ & $\begin{array}{l}\text { MCT }=9.17-0.23 \mathrm{~A}+0.28 \mathrm{~B}- \\
0.31 \mathrm{D}-0.25 \mathrm{E}+0.3 \mathrm{~F}-0.54 \mathrm{G}- \\
0.1 \mathrm{H}-0.27 \mathrm{I}-0.11 \mathrm{~J}\end{array}$ \\
\hline
\end{tabular}


Table 4: Results from the ANOVA analysis (continued)

\begin{tabular}{|c|c|c|c|}
\hline ANOVA & $\begin{array}{l}\text { Significant } \\
\text { factors }\end{array}$ & Discussion & $\begin{array}{c}\text { Regression equations derivate } \\
\text { from( } 1)\end{array}$ \\
\hline CM & $\begin{array}{l}A \\
B \\
E \\
H \\
J\end{array}$ & $\begin{array}{l}\text { A, is used to decrease costs in raw } \\
\text { material. } \\
\text { B was used for economic reasons to } \\
\text { decrease costs. } \\
\text { E used for reactive groups to react } \\
\text { with the rubber during vulcanisation } \\
\text { and generate a rubber/ fibre. } \\
\text { H is a natural fibre that has various } \\
\text { advantages: it is low cost, low } \\
\text { density, and a renewable resource } \\
\text { that decreases costs in the } \\
\text { formulation. } \\
J \text { is the vulcanising time that allows } \\
\text { the rubber/ fibre properties to be } \\
\text { improved. }\end{array}$ & $\begin{array}{l}\mathrm{CM}=14.71-0.21 \mathrm{~A}-0.25 \mathrm{~B}- \\
0.02 \mathrm{D}+0.51 \mathrm{E}+0.02 \mathrm{~F}+0.01 \mathrm{G}-0.58 \mathrm{H}- \\
0.01 I+0.69 \mathrm{~J}\end{array}$ \\
\hline EB & $\begin{array}{l}\text { None of the } \\
\text { factors have an } \\
\text { effect. }\end{array}$ & $\begin{array}{l}\text { The regression equation is not } \\
\text { significant. }\end{array}$ & $\begin{array}{l}\mathrm{EB}=676.57-35.78 \mathrm{~A}+94.10 \mathrm{~B}-18.23 \mathrm{D}- \\
64.88 \mathrm{E}+18 \mathrm{~F}-68.55 \mathrm{G}-75.49 \mathrm{H}- \\
10.68 \mathrm{I}+17.24 \mathrm{~J}\end{array}$ \\
\hline HSA & $\mathrm{B}$ & $\begin{array}{l}\text { J is the optimal vulcanising time } \\
\text { that achieves a greater amount of } \\
\text { cross-linking and improves the } \\
\text { product hardness. } \\
\text { B moderately improves the } \\
\text { plasticity and eases processing, } \\
\text { allowing segments of polymeric } \\
\text { chains mobility internally. }\end{array}$ & $\begin{array}{l}\mathrm{HSA}=71.52-0.77 \mathrm{~A}-2.56 \mathrm{~B}- \\
1.72 \mathrm{D}+0.77 \mathrm{E}-1.27 \mathrm{~F}- \\
1.22 \mathrm{G}+1.81 \mathrm{H}+0.77 \mathrm{I}-4.02 \mathrm{~J}\end{array}$ \\
\hline
\end{tabular}

In addition, it is observed that the columns are allocated letters $(A, B, D, E, F, G, H, I$ and J) that represent nine factors, while the rows show four responses (MCT, CM, HSA and TR). The interpretation will be made in the rows. MCT has $\mathrm{G}$ as a statistically significant factor, meaning that the changes in $\mathrm{G}$ from level 1 to level -1 have an effect on the response. For $\mathrm{CM}$ it is observed that $\mathrm{J}, \mathrm{H}, \mathrm{E}, \mathrm{B}$, and $\mathrm{A}$ have a significant influence on the response when they change from level 1 to level -1 . Note that EB was excluded from the analysis of the $\mathbf{D}$ global desirability function, because it decreased the potential of the analysis of the significant regression equations in approximately $10 \%$ of the equations, obtaining a less efficient solution. The HSA showed that B and J is statistically significant; thus there are significant effects when they change from level 1 to level -1 in the response. Lastly, TR shows that B, D, A and I are factors that, when changed from level 1 to level -1, influence the response. 


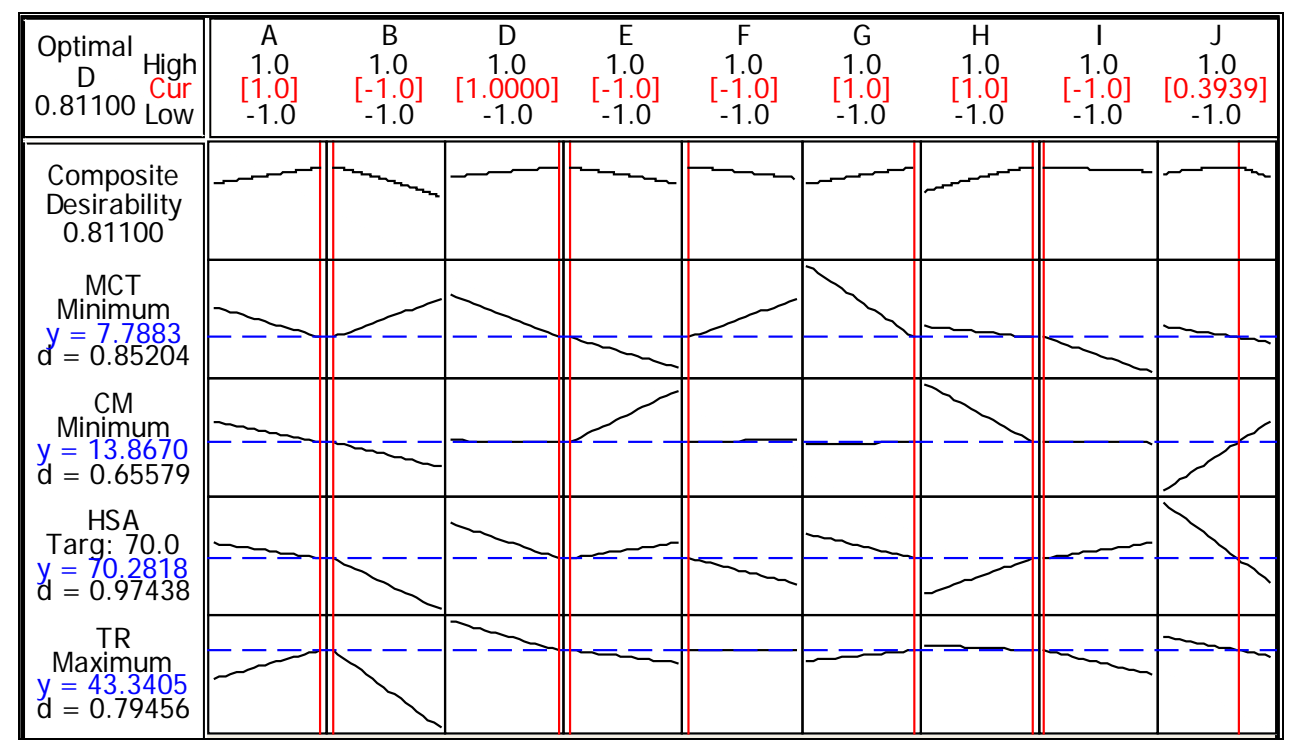

Figure 2: The global desirability function to evaluate the effect of each factor

It is important to describe the other components shown in the optimisation. The blue lines determine the $\mathbf{d}_{\mathbf{j}}$ individual desirability value of the responses. A $\mathbf{d}_{\mathbf{j}}$ value close to 1 means that the desirability degree in the response is acceptable; thus it is concluded that the four responses have an acceptable value. The $\mathbf{D}$ global desirability has a highly acceptable value, which means that the whole product and process are acceptable, reaching an optimal global response.

The red lines are a control, showing the point that indicates the selected level of the factor that meets the optimisation, and corresponds to the value that is marked between red brackets [ ] in the line referring to the factors.

In this way, the following objectives are met:

- Developing a sustainable product for vulcanised EPDM rubber with the introduction of natural fibres in the formulation;

- Implementing a non-conventional process of rubber vulcanisation where the manufacturing cycle time MCT and raw material costs CM are minimised;

- Maintaining the hardness HSA in industrial specifications; and

- Maximising the elongation to break EB and tear strength TR, through the multiresponse desirability function.

Therefore the best combination of coded factors and levels is: A [1], B [-1], D [1], E [-1], F [-1], G [1], H [1], I [-1] and J [0.4].

\section{CONCLUSION}

The optimisation of a non-conventional process of vulcanised EPDM rubber was carried out in this research with the multi-response desirability function, centred on a fractional factorial design $2_{\mathrm{III}}^{11-7}$ with five responses. The experimental strategy allowed only a few tests to be done while generating substantial knowledge of the non-conventional process of vulcanised rubber and ideal performance. 
The objective was to determine the best configuration of factors and their levels in order to:

- $\quad$ minimise the manufacturing cycle time (MCT);

- $\quad$ minimise the raw material cost $(\mathrm{CM})$;

- $\quad$ maintain the hardness at 70 in Shore A;

- maximise the elongation to breaking point as well as to tearing for a sustainable rubber/fibre product; and

- to implement an eco-efficient and non-conventional process of rubber vulcanisation.

The multi-response desirability function is a highly effective technique in the optimisation of the process and quality of products. From the eleven factors studied, only nine analysed factors have a statistically-significant effect on the responses of the rubber/fibre product and the newly-developed process. The experiment evaluated charges, oil, activators, accelerants, compatibilising agent, fibre, vulcanising agent, vulcanising time, and mixing temperature.

The responses were individually analysed to find the best ANOVA to obtain the adjusted regression equations. These regression equations satisfactorily describe the new process data. Therefore the best combination of decoded factors and levels is: A $(80 \mathrm{PCH}), \mathrm{B}(15$ $\mathrm{PCH}), \mathrm{D}(5 \mathrm{PCH}), \mathrm{E}(2 \mathrm{PCH}), \mathrm{F}(0.7 \mathrm{PCH}), \mathrm{G}(0.6 \mathrm{PCH}), \mathrm{H}(40 \mathrm{PCH}), \mathrm{I}(1 \mathrm{PCH})$ and J (7 minutes).

This arrangement allows us to conclude that the new process optimised with the multiresponse desirability function maintains the sustainable product with the required characteristics to meet the desired eco-efficiency and be environmentally friendly. Finally, the multi-response optimisation is an alternative that provides solutions to several problems of a product in a process. This allows process engineers to be more involved in the process and to identify more of the factors that make an impact on the product and the process.

\section{NOMENCLATURE}

$\begin{array}{ll}\text { HDPE } & \text { High density polyethylene } \\ \text { NR } & \text { Natural rubber } \\ \text { PP } & \text { Polypropylene } \\ \text { PE } & \text { Polyethylene } \\ \text { PA6 } & \text { Polyamide } 6 \\ \text { PS } & \text { Polystyrene } \\ \text { PLA } & \text { Polylactic acid } \\ \text { LDPE } & \text { Low density polyethylene } \\ \text { EPDM } & \text { Ethylene-propylene-diene-terpolymer } \\ \text { EPR-g-MA } & \text { Maleate ethylene propylene rubber } \\ \text { EPDM-g-MA } & \text { Maleic anhydride grafted EPDM } \\ \text { PP-MA } & \text { Polypropylene graft maleic anhydride } \\ \text { PE-MA } & \text { Maleic anhydride grafted polyethylene } \\ \text { MMA } & \text { Methyl-methacrylate } \\ \text { LMDPE } & \text { Linear medium density polyethylene }\end{array}$

\section{REFERENCES}

[1] Alawar, A., Hamed, A. \& Al, K. 2009. Characterization of treated date palm tree fiber as composite reinforcement. Composites: Part B, 40 (1), pp. 601-606.

[2] Amigó, V., Salvador, M., Sahuquillo, O., Llorens, R. \& Martí, F. 2008. Valoración de residuos de fibras vegetales como refuerzo de plásticos industrials. I Simposio Iberoamericano de Ingeniería de Residuos, 23-24 Julio, Castellón, España.

[3] Ruksakulpiwat, Y., Sridee, J., Suppakarn, N. \& Sutapun, W. 2009. Improvement of impact property of natural fiber-polypropylene composite by using natural rubber and EPDM rubber. Composites: Part B, 40 (7), pp. 619-622. 
[4] Shojaei, A. \& Fereydoon, M. 2009. Taguchi analysis of extrusion variables and composition effects on the morphology and mechanical properties of EPR-g-MA toughened polyamide 6 and its composite with short glass fiber. Materials Science and Engineering, 506 (1-2), pp. 45-57.

[5] Gava, M., Pagotto, I. \& Carmo, M. 2010. Natural silica fiber as reinforcing filler of nylon 6. Composites: Part B, 41 (1), pp. 98-105.

[6] Seong, K., Soo, B. \& J ae, Y. 2011. New hybrid method for simultaneous improvement of tensile and impact properties of carbon fiber reinforced composites. Carbon, 49 (15), pp. 5329-5338.

[7] Kord, B. 2011. Evaluation on the effect of wood flour and coupling agent content on the hygroscopic thickness swelling rate of polypropylene composites. BioResources, 6 (3), pp. 30553065.

[8] Zhao, Y., Qiu, J., Feng, H., Zhang, M., Lei, L. \& Wu, X. 2011. Improvement of tensile and thermal properties of poly(lactic acid) composites with admicellar-treated rice straw fiber. Chemical Engineering J ournal, 173 (2), pp. 659-666.

[9] Becerra, M., Shastri, R., Zitzumbo, R. \& García, J. 2011. Compuesto de polietileno de baja densidad y fibra de agave tequilana. Cultura Ciencia y Tecnología año, 8 (45), pp. 71-78.

[10] Chaochanchaikul, K., Jayaraman, K., Rosarpitak, V. \& Sombatsompop, N. 2012. Influence of lignin content on photodegradation in wood/HDPE composites under UV weathering. BioResources, 7 (1), pp. 38-55.

[11] Herrera, P. \& Valadéz, A. 2005. A study of the mechanical properties of short natural-fiber reinforced composites. Composites: Part B, 36 (8), pp. 597-608.

[12] Sanjuan, R. \& J asso, C. 2009. Effect of waste agave fiber on the reinforcing of virgin or recycled polypropylene. Rev. Mexicana de Ingeniería Química, 8 (3), pp. 319-327.

[13] Ismail, H. \& Shaari, S. 2010. Curing characteristics, tensile properties and morphology of palm ash/halloysite nanotubes/ ethylene-propylene-diene-monomer (EPDM) hybrid composites. Polymer Testing, 29 (7), pp. 872-878.

[14] Anuar, H. \& Zuraida, A. 2011. Improvement in mechanical properties of reinforced thermoplastic elastomer composite with kenaf bast fibre. Composites: Part B, 42 (3), pp. 462-465.

[15] Valente, M., Sarasini, F., Marra, F., Tirillò, J. \& Pulci, G. 2011. Hybrid recycled glass fiber/wood flour thermoplastic composites: Manufacturing and mechanical characterization. Composites: Part A, 42 (6), pp. 649-657.

[16] Viet, X., Ismail, H., Rashid, A., Takeichi, T. \& Vo, T. 2011. Mechanical properties and water absorption of kenaf powder filled recycled high density polyethylene/natural rubber biocomposites using MAPE as a compatibilizer. BioResources, 6 (3), pp. 3260-3271.

[17] Zabihzadeh, S., Omidvar, A., Marandi, M., Dastoorian, F. \& Mirmehdi, S. 2011. Effect of filler loading on physical and flexural properties of rapeseed stem/ PP composites. BioResources, 6 (2), pp. 1475-1483.

[18] Najafi, A. \& Khademi, H. 2011. Lignocellulosic filler/recycled HDPE composites: Effect of filler type on physical and flexural properties. BioResources, 6 (3), pp. 2411-2424.

[19] Singha, A. \& Rana, R. 2012. Natural fiber reinforced polystyrene composites: Effect of fiber loading, fiber dimensions and surface modification on mechanical properties. Materials and Design, 41, pp. 289-297.

[20] Safwan, M., Hui, O. \& Akil, H. 2013. Preparation and characterization of palm kernel shell/ polypropylene biocomposites and their hybrid composites with nanosilica. BioResources, 8 (2), pp. 1539-1550.

[21] Mahdavi, S., Kermanian, H. \& Varshoei, A. 2010. Comparison of mechanical properties of date palm fiber-polyethylene composite. BioResources, 5 (4), pp. 2931-2403.

[22] Acharya, S., Mishra, P. \& Mehar, S. 2011. Effect of surface treatment on the mechanical properties of bagasse fiber reinforced polymer composite. BioResources, 6 (3), pp. 3155-3165.

[23] López, R., Moscoso, F., Ortega, P., Mendizabal, E., Rodríguez, D. \& González, R. 2012. Rotational molding of polyethylene composites base on gave fibers. Polymer Engineering \& Science, 52 (12), pp. 2489-2497.

[24] Lárusson, L., Fischer, G. \& J önsson, J. 2013. Prefabricated floor panels composed of fiber reinforced concrete and a steel substructure. Engineering Structures, 46, pp. 104-115.

[25] Flores, P. 2009. Compostaje de dos materiales de bagazo de maguey tequilero (agave tequilana weber) y su determinación física y fisicoquímica, Centro Interdisciplinario de Investigación para el Desarrollo Integral Regional Unidad Oaxaca: Santa Cruz Xoxocotlán, Oaxaca, México, pp. 1-99.

[26] Laborde, A., Valencia, J., Hernández, J., Del Real, J. \& Laborde, M. 2011. Method for preparing a thermoplastic polymer mixture comprising fibres, agave residues and oxodegradable additives preparing biodegradable plastic articles. MX2011/000069, WIPO Patent Application WO/ 2011/ 155814.

[27] Iñiguez, G., Martínez, G., Flores, P. \& Virgen, G. 2011. Utilización de subproductos de la industria tequilera. Parte 9. Monitoreo de la evolución de compostaje de dos fuentes distintas de bagazo de agave para la obtención de un substrato para jitomate. Rev. Int. Contam. Ambie, 27 (1), pp. 47-59.

[28] Castaño, E. \& Domínguez, J . 2010. Diseño de experimentos: Estrategias y análisis en ciencia y tecnología. Querétaro: Universidad Autónoma de Querétaro, México. 
[29] Montgomery, D. 2004. Diseño y análisis de experimentos. Universidad Estatal de Arizona: Limusa Wiley.

[30] Gutiérrez, H. \& De La Vara, R. 2008. Análisis y diseño de experimentos. México: McGraw-Hill Interamericana.

[31] Derringer, G. \& Suich, R. 1980. Simultaneous optimization of several response variables. J ournal of Quality Technology, 12(4), pp. 214-219.

[32] Wang, Z., Wang, L., Wang, X. \& Hao, C. 2012. Deformation reversibility enhancement of thermoplastic vulcanizantes based on high density polyethylene and ethylene-propylene-diene terpolymer. Materials Chemistry and Physics, 134 (2-3), pp. 1185-1189.

[33] Milani, G. \& Milani, F. 2012. Optimization of extrusion production lines for EPDM rubber vulcanized with sulphur: A two-phase model based on finite elements and kinetic second order differential equation. Computers and Chemical Engineering, 43, pp. 173-190.

[34] Mohd, H., Mohd, G. \& Sahrim, A. 2012. Effect of antioxidants and fire retardants as mineral fillers on the physical and mechanical properties of high loading hybrid biocomposites reinforced with rice husks and sawdust. Industrial Crops and Products, 40, pp. 96-102.

[35] Morandim, A., Agnelli, J., Lancas, B., Magnabosco, R., Casarín, S. \& Bettini, S. 2012. Lignin as additive in polypropylene/coir composites: Thermal, mechanical and morphological properties. Carbohydrate Polymers, 87 (4), pp. 2563-2568.

[36] Avalos, F. \& Zapata, I. 2012. Química hoy, tópicos selectos de investigación. México, Saltillo, Coahuila: Universidad Autónoma de Coahuila.

[37] Stelescu, D., Airinei, A., Homocianu, M., Fifere, N., Timpu, D. \& Aflori, M. 2013. Structural characteristics of some high density polyethylene/ EPDM blends. Polymer Testing, 32 (2), pp. 187196.

[38] Hassan, H., Ateia, E., Darwish, N., Halim, S. \& El-Aziz, A. 2012. Effect of filler concentration on the physico-mechanical properties of super abrasion furnace black and silica loaded styrene butadiene rubber. Materials and Design, 34, pp. 533-540.

[39] Yasin, T., Khan, S., Young, N. \& Ahmad, R. 2012. Effect of polyfunctional monomers on properties of radiation crosslinked EPDM/ waste tire dust blend. Radiation Physics and Chemistry, 81, pp. 421-425.

[40] Zhang, B., Lu, X., Zhang, Z., Liu, Y., Kim, J. \& Xin, Z. 2010. Effect of carbon black content on microcellular structure and physical properties of chlorinated polyethylene rubber foams. Materials and Design, 31 (6), pp. 3106-3110.

[41] Xu, Q., Pang, M., Zhu, L., Zhang, Y. \& Feng, S. 2010. Mechanical properties of silicone rubber composed of diverse vinyl content silicone gums blending. Materials and Design, 31 (9), pp. 40834087.

[42] Khalf, A. \& Ward, A. 2010. Use of rice husks as potential filler in styrene butadiene rubber/linear low density polyethylene blends in the presence of maleic anhydride. Materials and Design, 31 (5), pp. 2414-2421.

[43] Samaržija, S., Jovanović, V., Marković, G., Konstantinović, S. \& Marinović, M. 2011. Nanocomposites base on silica-reinforced ethylene-propylene-diene-monomer/acrylonitrilebutadiene rubber blends. Composites: Part B, 42 (5), pp. 1244-1250.

[44] Chen, Y., Xu, C., Cao, L., Wang, Y. \& Cao, X. 2012. PP/EPDM-based dynamically vulcanized thermoplastic olefin with zinc dimethacrylate: Preparation, rheology, morphology, crystallization and mechanical properties. Polymer Testing, 31 (6), pp. 728-736.

[45] Harrington, J. 1965. The desirability function. Industrial Quality Control. 21. pp. 494-498. 